\section{Successful parathyroid tissue autograft after 3 years of cryopreservation: a case report}

\author{
Implante bem-sucedido de paratireoide \\ criopreservada por 3 anos: relato de caso
}

Ana K. N. Leite', Climério P. do N. Junior', Sérgio S. Arap', Ledo Massoni', Delmar M. Lourenço², Lenine Garcia Brandão', Fábio L. de M. Montenegro'

\section{SUMMARY}

After a total parathyroidectomy, well-established protocols for the cryopreservation of parathyroid tissue and for the delayed autograft of this tissue exist, especially in cases of secondary hiperparathyroidism (HPT) or familial or sporadic parathyroid hyperplasia. Although delayed autografts are effective, the published success rates vary from $10 \%$ to $83 \%$. There are numerous factors that influence the viability, and therefore the success, of an autograft, including cryopreservation time. Certain authors believe that the tissue is only viable for 24 months, but there is no consensus on how long the parathyroid tissue can be preserved. A 63-year-old male who was diagnosed with sporadic multiple endocrine neoplasia type 1 and primary hyperparathyroidism, and was submitted to a total parathyroidectomy and an autograft in the forearm. The implant failed, and the patient developed severe hypoparathyroidism in the months following the surgery. Thirty-six months after the total parathyroidectomy, the cryopreserved autograft was successfully transplanted, and hypoparathyroidism was reversed (most recent systemic parathyroid hormone, $\mathrm{PTH}$, of $36 \mathrm{pg} / \mathrm{mL}$, and total calcium of $9.1 \mathrm{mg} / \mathrm{dL}$; no oral calcium supplementation). The case presented here indicates that cryopreserved parathyroid tissue may remain viable after 24 months in storage, and may retain the capacity to reverse permanent postsurgical hypoparathyroidism. These data provide reasonable evidence that the time limit for cryopreservation remains undetermined and that additional research would be valuable. Arq Bras Endocrinol Metab. 2014;58(3):313-6

\section{SUMÁRIO}

O implante de tecido paratireoideano criopreservado após paratireoidectomia total é um procedimento bem estabelecido e, embora tenha sua eficácia comprovada, as taxas de sucesso variam de $10 \%$ a $83 \%$ na literatura. 0 tempo de criopreservação é um dos diversos fatores relacionados ao sucesso do implante. Alguns autores defendem que o tecido permanece viável até 24 meses de criopreservação, no entanto, não há consenso. Homem de 63 anos diagnosticado com neoplasia endócrina múltipla tipo I e hiperparatireoidismo primário foi submetido a paratireoidectomia total e autoimplante em membro superior. 0 implante falhou e o paciente desenvolveu hipoparatireoidismo. Após 36 meses da paratireoidectomia total, foi realizado o implante de paratireoide criopreservada, com sucesso. 0 hipoparatireoidismo foi revertido e o paciente permanece sem suplementação de cálcio e PTH sistêmico de $36 \mathrm{pg} / \mathrm{mL}$ e cálcio total de $9,1 \mathrm{mg} / \mathrm{dL}$. 0 caso apresentado mostra que o tecido paratireoideano criopreservado pode permanecer viável após 24 meses e há possibilidade de reverter o hipoparatireoidismo pós-cirúrgico. Isso traz evidência de que o tempo limite de criopreservação permanece incerto e que novas pesquisas seriam de grande valia. Arq Bras Endocrinol Metab. 2014;58(3):313-6
${ }^{1}$ Hospital das Clínicas, Faculdade de Medicina da Universidade de São Paulo (HCFMUSP), Head and Neck Surgery Section, Department of Surgery, São Paulo, SP, Brazil ${ }^{2}$ HCFMUSP, Endocrine Genetics Unit, Endocrinology Division, São Paulo, SP, Brazil
Correspondence to: Ana K. N. Leite

Av. Dr. Enéas de Carvalho Aguiar, 255 $8^{\circ}$ andar, sala 8174 05403-900 - São Paulo, SP, Brazil circabpesc.ichc@hc.fm.usp.br

Received on June/19/2013 Accepted on Jan/28/2014 


\section{INTRODUCTION}

$\mathrm{T}$ he cryopreservation of parathyroid tissue after a total parathyroidectomy was experimentally studied in 1974 (1), and the first successful transplant of a cryopreserved parathyroid autograft in humans was reported in 1977 (2). Since this transplant, the procedure has been utilized in parathyroid surgery, especially in cases of secondary hiperparathyroidism (HPT) stemming from chronic renal insufficiency, or of primary HPT secondary to familial or sporadic parathyroid hyperplasia. Parathyroid tissue cryopreservation is a well-established technique, and the transplantation of an autograft after the initial surgery potentially cures persistent hypoparathyroidism. Although the effectiveness of a synchronous parathyroid tissue autograft during parathyroidectomy is remarkable (3), the published success rates for delayed autografts vary widely, from $10 \%$ to $83 \%$ (4-8). A primary reason for these conflicting results is that the maximum cryopreservation time that preserves parathyroid tissue viability and functionality is poorly defined.

Certain authors believe that cryopreserved parathyroid tissue is unlikely to remain viable after 24 months in storage (9), and that the storage time should therefore be limited to this timeframe. There are no conclusive data on the effect of time on the vitality of the cryopreserved tissue $(10,11)$.

We report a successful autograft performed after 36 months of cryopreservation, rendering oral calcium and calcitriol supplementation unnecessary for the patient, and providing a significant improvement in his quality of life.

\section{CASE REPORT}

This case report was approved by the Institucional Review Board.

In 2004, a 63-year-old male with a previous clinical history of multiple therapeutic procedures for nephrolithiasis developed sudden amaurosis after surgery for decompression of a disc hernia. Brain computerized tomography revealed a non-functioning pituitary macroadenoma. Transsphenoidal surgery was performed because of pituitary apoplexy.

During the follow-up, the patient was diagnosed with primary HPT. Serum calcium level was $11.9 \mathrm{mg} /$ $\mathrm{dL}$ (normal: $8.6-10.2 \mathrm{mg} / \mathrm{dL}$ ), and serum parathyroid hormone (PTH) level was $273 \mathrm{pg} / \mathrm{mL}$ (normal: 16-
$87 \mathrm{pg} / \mathrm{mL}$ ). The patient was clinically diagnosed with multiple endocrine neoplasia type 1 (MENl) according to the MEN1 2001 Consensus criteria. There was no familial history of MENl. The two sons were asymptomatic, and the initial biochemical screening for the presence of MEN1-related tumors (HPT, functioning pituitary adenoma, insulinoma, and gastrinoma) was negative. At that time, genetic analysis was not available.

In March 2007, the patient underwent a total parathyroidectomy with an autograft in the forearm, and the parathyroid tissue was cryopreserved. Following the protocol of the institution, after harvesting the parathyroid tissue, it was sliced in small pieces of $2 \mathrm{~mm}$ at the operating room. These fragments were stored and transported to the laboratory in RPMI 1640 (Roswell Park Memorial Institute) supplemented with antibiotics $(200 \mathrm{~g} / \mathrm{mL}$ streptomycin and ampicillin). The tissue was then washed, and the fragments were placed in cryotubes with RPMI 1640, 50\% fetal bovine serum, and $10 \%$ dimethylsulphoxide (DMSO). The cryotubes were placed in a polystyrene foam box in a freezer at $-70^{\circ} \mathrm{C}$, and then stored in liquid nitrogen $\left(-180^{\circ} \mathrm{C}\right)$.

In March 2010, the patient remained dependent on high doses of oral calcium and calcitriol (4.5 g of calcium carbonate and $0.25 \mathrm{mcg}$ of calcitriol, daily), and systemic PTH was undetectable $(<3 \mathrm{pg} / \mathrm{mL})$. There were no other possible causes of hypocalcemia. Serum phosphorous level was $4.0 \mathrm{mg} / \mathrm{dL}$ (normal 2.7-4.5 $\mathrm{mg} / \mathrm{dL}$ ), creatinine was $1.03 \mathrm{mg} / \mathrm{dL}$ (normal 0.7-1.2 $\mathrm{mg} / \mathrm{dL}$ ), and magnesium $1.96 \mathrm{mg} / \mathrm{dL}$ (normal 1.58$2.55 \mathrm{mg} / \mathrm{dL}$ ). The unexpected absence of pancreatic neuroendocrine tumors at 70 years of age, the negative family history, the surgical finding of parathyroid adenoma, and the synchronous autograft failure with persistent hypoparathyroidism strongly suggested the diagnosis of sporadic MENl. This hypothesis was strengthened by the negative result from MENl gene analysis. Therefore, a new parathyroid implant was offered to the patient.

A cryopreserved parathyroid tissue autograft was transplanted under local anesthesia three years after the total parathyroidectomy. Before transplantation, the parathyroid tissue was rapidly thawed at $37^{\circ} \mathrm{C}$, and rinsed with RPMI 1640 in an ice bath to remove DMSO and serum. Fragments were then rinsed in sterile saline solution and transported to the operating room in RPMI. Before the implantation, the tissue was rinsed in sterile saline and implanted in the forearm. 
Three months after the implant, the patient had serum PTH level of $15 \mathrm{pg} / \mathrm{mL}$ and total serum calcium concentration of $10.0 \mathrm{mg} / \mathrm{dL}$. Therefore, he was advised to discontinue oral calcium and calcitriol supplementation. Five months after surgery, the parathyroid implant was functioning. HPT secondary to vitamin $\mathrm{D}$ deficiency (25-OHD [25-hydroxy vitamin D] of 14 $\mathrm{ng} / \mathrm{mL}$; normal: $30-100 \mathrm{ng} / \mathrm{mL}$ ) was diagnosed (systemic PTH of $62 \mathrm{pg} / \mathrm{mL}$, arm graft PTH of $538 \mathrm{pg} /$ $\mathrm{mL}$, total calcium of $8.8 \mathrm{mg} / \mathrm{dL}$, and 25-OHD of 19 $\mathrm{ng} / \mathrm{mL}$ ), and vitamin D supplementation was initiated. Nine months after treatment, HPT secondary to vitamin D deficiency was corrected (systemic PTH of 41 $\mathrm{pg} / \mathrm{mL}$, arm graft PTH of $204 \mathrm{pg} / \mathrm{mL}$, total calcium of $8.9 \mathrm{mg} / \mathrm{dL}$, and $25-\mathrm{OHD}$ of $39 \mathrm{ng} / \mathrm{mL}$ ). At the last appointment, in March 2013, three years after the implant, the patient was asymptomatic without calcium or calcitriol supplementation and had a functioning implant (systemic PTH of $36 \mathrm{pg} / \mathrm{mL}$, total calcium of 9.1 $\mathrm{mg} / \mathrm{dL}$, and 25-OHD of $38 \mathrm{ng} / \mathrm{mL}$ ).

\section{DISCUSSION}

The present case indicates that cryopreserved parathyroid tissue may remain viable after several months in storage and can reverse permanent postsurgical hypoparathyroidism after 36 months of cryopreservation. Notably, the successful autograft eliminated the risks related to permanent hypoparathyroidism and significantly improved the patient's quality of life. The present case contradicts recent clinical reports (8) and indirect laboratory evidence (9) that indicate that tissue is nonviable after 24 months of cryopreservation.

Improvements in PTH levels and an eventual recurrence of HPT may occur in some patients who undergo total parathyroidectomy because of hyperplasia of a supernumerary parathyroid gland, especially in cases of familial HPT syndromes, such as MENl (12). In the present case, besides the normal calcium metabolism, the PTH gradient in the arm graft proved that the cryopreserved parathyroid tissue was functional.

Permanent hypoparathyroidism is defined as hypocalcemia requiring calcium and calcitriol supplementation beyond six months after parathyroid surgery (3), but hungry bone syndrome causes confusion regarding this definition. This definition is inappropriate in familial HPT. In a subset of 16 patients with familial MEN1-associated HPT, calcium and calcitriol supplementation were required for 4 to 15 months after total parathyroidectomy, with an increase in graft function occurring months after the surgery (13).

Although the reported success rates of autotransplantation with cryopreserved parathyroid tissue are lower than in those with synchronous autografts $(4,7,14)$ the reports differ in their opinions $(3,15)$. Numerous factors affect the success rate of metachronous autografts, such as the cryopreservation process itself, the amount of preserved and grafted tissue, the time between harvest and cryopreservation, and the time between cryopreservation and grafting $(3,10,16,17)$.

In a retrospective study of the viability (by trypan blue dye exclusion) of 106 random cryopreserved parathyroid specimens, $71 \%(10 / 14)$ of the samples stored for less than 24 months were deemed viable, whereas only $1 \%(1 / 92)$ of the samples stored for longer than 24 months were deemed viable. The authors suggested that parathyroid cryopreservation should be limited to 24 months, despite the fact that one specimen displayed evidence of viability after 120 months of cryopreservation (9).

In another experimental study, Smeds and cols. analyzed the viability of cryopreserved tissue stored for 9 to 55 months after xenotransplantation in mice and concluded that there was no correlation between the quality of the transplant and cryopreservation time (10). In vitro studies demonstrated that, compared with fresh tissue, cryopreserved bovine parathyroid tissue produced less PTH. However, in that study, PTH production was not affected by the storage time (18).

Certain authors have raised the issue of the cost and effort required for cryopreservation because only a small percentage of patients will require a delayed autograft. This issue is one of the reasons why particular authors have proposed cryopreservation time limits, such as 24 months, or suggested the identification of patients with an increased risk of permanent hypoparathyroidism $(3,9)$. It is important to remember that permanent hypoparathyroidism can be quite harmful because it generates additional costs due to medication, frequent laboratory testing, and possible hospital stays, besides decreasing the quality of life. If the cryopreserved tissue is discarded, no other options remain for a definitive treatment.

Recently, it was reported that bone mineral and renal complications in familial MENl-related HPT are early-onset, progressive, frequent, extensive, and severe with a high frequency of urolithiasis and demineralization of cortical and cancellous bone (19). Therefore, 
the acceptable surgical options for the treatment of HPT associated with familial or sporadic MENl are subtotal parathyroidectomy or total parathyroidectomy with an immediate autograft (20). Both techniques carry the risk of permanent hypoparathyroidism (12). The possibility of tissue cryopreservation is attractive in the context of multiglandular disease because, in many cases, tissue cryopreservation offers a solution for permanent hypoparathyroidism, even after subtotal parathyroidectomy. Multiglandular disease associated with sporadic or familial hyperplasia occurs in 10-15\% of all HPT cases and represents the primary cause of surgical failure in terms of recurrent/persistent HPT and post-surgical complications, especially permanent hypoparathyroidism. It is possible that longer storage of the cryopreserved parathyroid tissue may be useful in those patients with HPT and multiglandular disease, or in cases where familial HPT syndromes are initially suspected, such as in the sporadic MENl case reported here. This case provides reasonable evidence that the time limit for cryopreservation has yet to be established, and that additional research would be valuable.

Acknowledgments: we would like to thank Malebranche Berardo Carneiro da Cunha Neto and Nina Rosa de Castro Musolino for the diagnosis of MEN type $\mathrm{l}$ and patient referral; and Sergio Pereira de Almeida Toledo and Rodrigo de Almeida Toledo for their work with genetic testing for MEN type 1 .

Disclosure: no potential conflict of interest relevant to this article was reported.

\section{REFERENCES}

1. Wells SA Jr, Christiansen C. The transplanted parathyroid gland: evaluation of cryopreservation and other environmental factors which affect its function. Surgery. 1974;75(1):49-55.

2. Wells SA Jr, Gunnells JC, Gutman RA, Shelburne JD, Schneider $A B$, Sherwood LM. The successful transplantation of frozen parathyroid tissue in man. Surgery. 1977;81(1):86-90.

3. Schneider R, Ramaswamy A, Slater EP, Bartsch DK, Schlosser K. Cryopreservation of parathyroid tissue after parathyroid surgery for renal hyperparathyroidism: does it really make sense? World J Surg. 2012;36(11):2598-604.

4. Feldman AL, Sharaf RN, Skarulis MC, Bartlett DL, Libutti SK, Weinstein LS, et al. Results of heterotopic parathyroid autotransplantation: a 13-year experience. Surgery. 1999;126(6):1042-8.
5. Caccitolo JA, Farley DR, van Heerden JA, Grant CS, Thompson $\mathrm{GB}$, Sterioff $\mathrm{S}$. The current role of parathyroid cryopreservation and autotransplantation in parathyroid surgery: an institutional experience. Surgery. 1997;122(6):1062-7.

6. Wagner PK, Seesko HG, Rothmund M. Replantation of cryopreserved human parathyroid tissue. World J Surg. 1991;15(6):751-5.

7. Herrera M, Grant C, van Heerden JA, Fitzpatrick LA. Parathyroid autotransplantation. Arch Surg. 1992;127(7):825-9; discussion 9-30.

8. Borot S, Lapierre V, Carnaille B, Goudet P, Penfornis A. Results of cryopreserved parathyroid autografts: a retrospective multicenter study. Surgery. 2010;147(4):529-35.

9. Guerrero MA, Evans DB, Lee JE, Bao R, Bereket A, Gantela S, et al. Viability of cryopreserved parathyroid tissue: when is continued storage versus disposal indicated? World J Surg. 2008;32(5):836-9.

10. Smeds S, Trulsson L, Garovoy M, Gumbert M, Clark OH. Survival of human parathyroid tissue xenotransplanted in nude mice after 9 to 55 months' cryopreservation. APMIS. 1999;107(4):445-50.

11. Ulrich F, SteinmullerT, Rayes N, Kleespiess A, Grzonka S, Gerlach $\mathrm{J}$, et al. Cryopreserved human parathyroid tissue: cell cultures for in vitro testing of function. Transplant Proc. 2001;33(1-2):666-7.

12. d'Alessandro AF, Montenegro FL, Brandao LG, Lourenco Jr DM, Toledo Sde A,Cordeiro AC. Supernumerary parathyroid glands in hyperparathyroidism associated with multiple endocrine neoplasia type 1. Rev Assoc Med Bras. 2012;58(3):323-7.

13. Coutinho FL, Lourenco DM Jr, Toledo RA, Montenegro FL, Correia-Deur JE, Toledo SP. Bone mineral density analysis in patients with primary hyperparathyroidism associated with multiple endocrine neoplasia type 1 after total parathyroidectomy. Clin Endocrinol (Oxf). 2010;72(4):462-8.

14. Rothmund M, Wagner PK. Assessment of parathyroid graft function after autotransplantation of fresh and cryopreserved tissue. World J Surg. 1984;8(4):527-33

15. Wagner PK, Rumpelt HJ, Krause U, Rothmund M. The effect of cryopreservation on hormone secretion in vitro and morphology of human parathyroid tissue. Surgery. 1986;99(3):257-64.

16. Barreira CE, Cernea CR, Brandao LG, Custodio MR, Caldini ET, de Menezes, et al. Effects of time on ultrastructural integrity of parathyroid tissue before cryopreservation. World J Surg. 2011;35(11):2440-4.

17. de Menezes Montenegro FL, Custodio MR, Arap SS, Reis LM, Sonohara S, Castro IV, et al. Successful implant of long-term cryopreserved parathyroid glands after total parathyroidectomy. Head Neck. 2007;29(3):296-300.

18. McHenry CR, Stenger DB, Calandro NK. The effect of cryopreservation on parathyroid cell viability and function. Am J Surg. 1997;174(5):481-4.

19. Lourenco DM Jr, Coutinho FL, Toledo RA, Montenegro FL, Correia-Deur JE, Toledo SP. Early-onset, progressive, frequent, extensive, and severe bone mineral and renal complications in multiple endocrine neoplasia type 1-associated primary hyperparathyroidism. J Bone Miner Res. 2010;25(11):2382-91.

20. Montenegro FL, Lourenco DM Jr, Tavares MR, Arap SS, Nascimento CP Jr, Massoni Neto LM, et al. Total parathyroidectomy in a large cohort of cases with hyperparathyroidism associated with multiple endocrine neoplasia type 1: experience from a single academic center. Clinics (Sao Paulo). 2012;67(Suppl 1):131-9. 